\title{
PROFESSIONAL SOCIALIZATION AS SUCCESSFUL CAREER PRESUMPTION
}

\author{
Dalia Augienè \\ Šiauliai University, Lithuania \\ E-mail: augiene@gmail.com
}

Work is regarded as the most important and even the most essential human activity, however, the type of working activity, changes, unemployment influence person's and society life. Most of the people define their status and importance in society according to their profession, therefore self-consciousness, self-perception and self-respect are dependent upon it. The occupied status gives social value and society recognition. Most of social contacts take place in work environment. In our culture the society encourages each of its member to work, who is considered at least a little independent and we are used to regard the ability to work and reconcilement with such a situation as important conditions of psychic health. The choice of profession, its acquisition, work itself determine people's life. Work occupies quite a big or even the main part of personality's life time. For many people work is the axis of life - both in everyday life and seeking for big goals. One can regard work as "boredom, torture, an inevitable evil" however it would be difficult to deny, that this is a fundamental part of our life. We spend plenty of time working and it is obvious, that working models form many aspects of our existence - beginning with friends and finishing with leisure time. Human lifestyle directly depends on the chosen profession, and physical, psychic health very often on, how a person feels at work. While working people set in order and control their world, physical and social environment in which they live, create various material and spiritual values satisfying their demands. Therefore, basically one can claim, that professional activity and professional achievements define not only self-realisation field, but also human income, status in society, social prestige (value), form conditions for social mobility (social status change possibilities), allow feeling an important member of society. It is obvious, that every person, having chosen a profession, dreams about future perspectives and a successfully formed career.

Not only one's conscious ability and trait cognition, right professional decision, paying attention to calling, perfect professional (theoretical and practical) preparation determine a successful career. Professional socialisation occupies an important place in human life and professional activity. Each of us experiences both primary, and secondary socialisation. Primary socialisation is associated with childhood, secondary - with later integration into the society. Professional integration is one of the compound secondary socialisation parts, lasting all life, because there are no limits for professional skilfulness. Professional 
socialisation is an individual process, which is determined by personality peculiarities and specifics of the profession.

Professional socialisation is a process, during which people selectively acquire values, attitudes, interests, behaviour models, abilities, knowledge, i.e. the culture of that profession, professional group, which they belong to. Profession exists as a complex structural reality, into which are involved people starting their professional career and which is forming them as professionals. Professional socialisation is a long and complicated process. The elements of early professional socialisation one can already discern in secondary school, when a student starts to understand that profession, activity direction choice is the most important decision in life, determining his life quality and social status. School, person's value understanding, dominating profession image in society, forming understanding, that work consolidates and justifies human existence in society form the foundation of professional socialisation. Professional socialisation process becomes more dynamic the student having chosen the studies and going deep into profession peculiarities, acquiring knowledge, forming abilities and skills, and acquiring new competencies. This process becomes even more intense when from theoretical teaching/learning one goes to practical bases. During the studies and practices professional attitudes of young people, values, professional behaviour models, beliefs, devotion to work are formed, motivation is stimulated, supporting the efficiency of the activity and continuous professional improvement, competence development.

From the social point of view, professional socialisation forms conditions for a person to become the one society regards him and accepts as a representative of a corresponding activity or profession, from whom one can expect certain behaviour, speaking, manners, skills, ability to perform one or another role, appearance and so on, for example, military posture (for an officer), clerical speech (for a priest), ability to encourage a patient (for a doctor). Professional role involves certain activity, emotions and attitudes, which are related to that activity (Berger, 1995). Our profession defines society expectations: how we must behave, dress up and so on. J. Holland $(1985$, p.8) points out: "Occupations represent a way of life, an environment rather than a set of isolated work functions or skills. To work as a carpenter means not only to use tools, but also to have a certain status, community role, and a special pattern of living". Thus, in many respects, an individual is described by the work he does. Based on this, social professional stereotypes form how must a person of a corresponding profession, occupying a certain position look and behave.

Professional socialisation forms conditions for an individual's professionalization, which allows a person to acquire specific science knowledge, to accumulate it, to develop one's competences, form, construct professional culture and professional identity, try to strengthen it. This corresponds to professional socialisation dynamics, in which an amateur becomes a socially acknowledged professional. Professionality is one of the essential professional socialisation characteristics. Individual's professionalisation reveals competence necessary for professional activity, for working place preservation acquisition and improvement and a legal possibility to occupy certain positions and career positions. Individual's professionalisation decreases or eliminates his unemployment risk i.e., ensures a successful social and professional integration. Any institution seeks to form its own personnel from professional employees, to accumulate and develop their available social, cultural potential, to form conditions for every employee's self-expression and professional improvement and professional identity construction.

Calling and value aspect, norms, as value concretisation measure occupy a special place in professional socialisation. Calling and values arise one from another, exist not separately but jointly and supplement each other, and depend on personality traits. Professional calling and value identification and realisation are closely interrelated and directly dependent on one 
Baltic Journal of Career Education and Management

\section{6}

another, calling is forming determined by values. People, who can match personal values with profession, i.e. realise personal values in professional activity, live a happy, full of sense and full life. In the case, when professional activity is based on pragmatic attitude, it becomes only "people's livelihood", but not a source of full life. Values perceived in the right way and professional behaviour directed in the appropriate direction form an individual's career. A person, whose professional activity is encouraged by values and who directs efforts to control his professional behaviour, such person is able not only to manage his career, but also to constantly learn and change, to adapt to changes. In the professional socialisation process values change, a person takes over the values honoured in the profession.

Unsuccessful individual's professional socialisation consequences - work dissatisfaction, absenteeism, negative attitude to professional activity - affect organisation's work effectiveness as well, and on the contrary, successful professional socialisation creates bilateral benefit. Realising one's expectations an employee feels work satisfaction, obligation for the organisation, by qualitative work seeks common organisation goals.

Professional socialisation as a process does not take place very fast, it requires big individual, structure, activity changes. This is a change over a long period of time, during which every individual must find enough time for improvement, renewal, professional identity formation and legitimisation.

\section{References}

Berger, P. L. (1995). Sociologija. Humanistinis požiūris [Sociology. Humanistic approach]. Kaunas: Litterae Universitatis.

Holland, J. (1985). Making Vocational Choices. A theory of vocational personalities and work environments. London.

Received: October 28, 2017

Accepted: December 15, 2017
Dalia Augienè

Ph.D., Senior Researcher at the University of Siauliai, Faculty of Education Sciences and Social Welfare, Department of Education \& Psychology, P. Visinskio Street 25, LT-76351 Siauliai, Lithuania.

E-mail: augiene@gmail.com

Website: http://www.su.lt 